\title{
Editorial
}

\section{Sem modéstias fingidas}

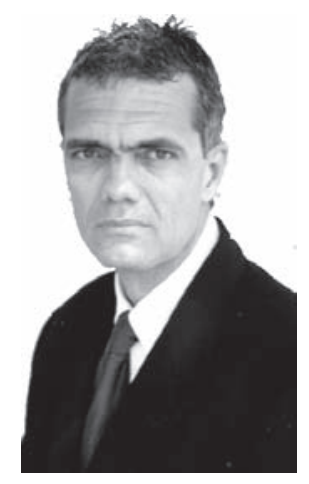

Prof. Dr. Marco Antonio Guimarães da Silva

\footnotetext{
* Editor cientifico de Fisioterapia Brasil

Pós Doutorado na UFRJ

Professor de mestrado recomendado

pela CAPES
}

Hesitando entre continuar a recém iniciada corrida em volta da lagoa e voltar a casa para buscar a minha câmara fotográfica e desenhar com a luz mágica daquela tarde de domingo todo entorno deste sítio com o maior IDH do mundo (!?),opto, com muitas reticências, pela melhoria do meu já combalido condicionamento físico, dando seqüência à atividade então iniciada. Contava, também, que os próximos oito quilômetros de corrida me permitiriam, como já o fazem há vários anos, pensar e equacionar uma série de questões que ainda reclamavam soluções e finalizações. Dentre todas estas pendências, a mais urgente debruçava-se sobre a elaboração do editorial da Revista Fisioterapia Brasil, agora indexada na base de dados LILACS (BIREME)

Tínhamos a certeza de que o grande esforço, feito por toda nossa equipe, para que a revista mantivesse a periodicidade prometida seria recompensado. Era também de nosso conhecimento que já existiam revistas de fisioterapia indexadas, com duas edições anuais. Seríamos, na verdade já o somos, a primeira revista indexada com seis edições anuais no Brasil. Parece-me que aí está o grande desafio. Manter as seis edições anuais nos custa muito esforço e cuidado, para que os artigos possam alcançar a qualidade que uma revista a ser indexada ou já indexada requer. Mas já temos a qualidade que desejamos? Ainda não, e sabem disso todos aqueles que, como meus alunos de Doutorado, Mestrado ou Especialização, compartilharam comigo, especialmente nos dez últimos anos, a tarefa de, minuciosamente, analisar um artigo científico.

Antes que se façam leituras equivocadas do que acabo de escrever, é bom esclarecer que pouquíssimas revistas ou periódicos no mundo poderiam escapar ilesas de uma rigorosa análise. É evidente, que ha vários aspectos a serem avaliados e, em algumas situações, fazer concessões pode ser o caminho para iniciar ou manter o escoamento das produções cientificas. Uma dessas concessões estaria no não questionamento do correto delineamento da investigação cientifica predecessora do artigo. Podemos encontrar um exemplo muito claro do que falo no trabalho, já citado por mim em outro editorial, que o Departamento de Saúde Pública dos Estados Unidos (Agency for Health Care Policy and Research- $A C P H, 1994$ ) realizou sobre a qualidade e eficácia dos procedimentos diagnósticos e terapêuticos para tratamento da dor lombar. A metodologia do referido trabalho centrava-se na análise do que estava publicado sobre o tema em periódicos de diversos países. Para surpresa geral, à época, nenhum dos procedimentos fisioterapêuticos para dor lombar encontrava respaldo cientifico, ou seja, não havia evidências que autorizassem os seus autores a afirmar que o método terapêutico em questão era eficaz. 
Apesar disto, os artigos que traziam estes resultados e procedimentos à comunidade acadêmica estavam publicados em periódicos de impacto (indexados pelo Medline).

Observa-se, também, com relativa freqüência, que se estabelecem relações de causalidade e conclusões de eficácia de terapias baseadas apenas em uma estatística descritiva. Há uma negligência em relação à estatística inferencial, sem que esteja estabelecido o nível de significância estatística (valor p) ou intervalos de confiança. Os vieses de confundimento, aferição e seleção não são, em muitas situações, neutralizados e nos fazem interpretar com muita cautela os resultados apresentados pelos autores. A redação é mal estruturada e não demonstra, em alguns casos, uma coerência contextual, com títulos geradores de sérios equívocos e completamente desvirtuados do objetivo do trabalho. Mas, como já dissemos, a situação não se restringe a este ou àquele periódico, é uma questão generalizada, o que, contudo, não nos exime de buscar soluções para equacionamento do problema.

Com essas observações, queremos sugerir àqueles que nos privilegiam e nos elegem como periódico que nos enviem artigos que apresentem - no caso de trabalhos originais - a estatística inferencial com o respectivo p de alfa, a autorização do comitê de ética do local onde se realizou o experimento, e o termo de consentimento dos pacientes que compuseram os grupos amostrais (para casos de aplicação de técnicas terapêuticas em seres humanos).

Embora as normas de Vancouver (conjunto de regras seguidas pela maior parte das revistas indexadas) não estabeleçam posições para os artigos de revisão, estamos orientando aos que nos enviam estes tipos de artigos, que formatem os seus trabalhos com os seus conteúdos distribuídos em uma introdução, um desenvolvimento e uma conclusão, respectivamente enumerados com romano.

Poderíamos seguir adiante comentando os problemas mais usuais, mas basta de críticas, sugestões e análises e suportemos cada coisa a seu tempo, como tão bem nos ensina Schopenhauer em a Arte de Ser Feliz: Que nada nos prive, neste momento, de curtir a felicidade e o prazer de sermos uma revista indexada. Não foi à toa que busquei para esse título algumas palavras perdidas que li em um dos textos de Cinco Escritos Morais (Umberto Eco) ou em a Bagagem do Viajante (José Saramago), dois livros que sempre releio, com grande prazer, em minhas intermináveis viagens aéreas. Não estou bem certo se essas palavras vem do ilustre e erudito filho de Piemonte ou do Nobel de Azinhaga, ainda que me incline a pensar de que tenham sido escritas com a pena lusitana...

Sem modéstias fingidas, que aspiremos à posição número um no cenário científico-editorial mundial da fisioterapia. Chegaremos lá. Acreditem. 